\title{
Unbearable Fadistas: António Variações and Fado as Queer Praxis
}

\author{
DANIEL DA SILVA
}

Columbia University

\begin{abstract}
António Variações's first single, Povo que lavas no rio/Estou além (1982), offers a radical version of Amália Rodrigues's fado "Povo que lavas no rio" (1962). This article considers Variações as fadista in order to think fado as queer praxis. Though Variações's debut release was a commercial success, his turn as fadista provoked critical derision for what, I argue, is a trans formation of the genre's gendered codes and practices. Variações's queer masculinity gives body and voice to the transgressive sexuality enmeshed within gendered and fetishized repertoires of fado that are most recognizable in the myths and voices of the genre's divas. This article locates Variações within a fado genealogy, from Maria Severa to Amália Rodrigues, of performers who have similarly been unbearable in body and voice. The purpose of this is to draw attention to fado's affective dispersions of sex and reveal how the genre has coalesced in relation to queer tactics and people throughout its history.
\end{abstract}

Keywords: Trans, performance, gender, sex, affect, improvisation

António Variações's recording debut, Povo que lavas no rio/Estou além (1982), launched the performer from a fixture of Lisbon's post-revolution underground music scene to national star. His career as a singer-songwriter and performer ended abruptly with his death in 1984, from complications most likely 
attributable to HIV/AIDS; ${ }^{1}$ however, he left two full-length albums and an archive of music videos and performances that enmesh progressive pop and new wave influences with allusions to homosexuality and the rhythms and registers of Portuguese popular culture and folkloric practices. Since his death, his celebrity has grown: street names memorialize him, his life and work have been the subject of TV programs, other Portuguese musicians have recorded his music, and in December 2017, the Universidade de Coimbra organized the first academic conference dedicated solely to him. Though he is now hailed as "o inventor da pop portuguesa" (Abreu), his debut release offers a version of Variações as fadista in a remake of the iconic fado "Povo que lavas no rio" that provokes a consideration of his transgressive art and sexuality as it is expressed and performed through a more conventional Portuguese music genre.

Focusing on his 1982 recording and TV performance of "Povo que lavas no rio," this article examines how Variações works through the feminine forms of fado in a trans formation of fadista that embodies the deviant sexuality of Maria Severa, the genre's first diva, and takes up Amália Rodrigues's imprint on Portuguese affective heritage as fado's most celebrated star. Central to this analysis is Jack Halberstam's insight that trans functions as a "relationality [that] describes not simply an identity but a relation between people, within a community, or within intimate bonds. [...] Transgender proves to be an important term not to people who want to reside outside of categories altogether but to people who want to place themselves in the way of particular forms of recognition" (In a Queer Time and Place 85). Variações as a trans formation of fadista exposes a relation between the affective resonances of the genre, the gendered labor and marked sexuality of its female performers, and the artist's queer masculinity, locating him within a fado history of risk-laden non-normative embodiments.

\section{Variações's Voltinhas in 1980s Lisbon}

Journalist and biographer Manuela Gonzaga locates Variações in Lisbon's "demi-monde" of the late 1970s and early 1980s, populated by "travestis, jovens

\footnotetext{
1 The official cause of death is recorded as bronchial pneumonia, though friends attest to Variações's HIV/AIDS diagnosis. His family remained resistant to this diagnosis due to the unfavorable public perception that came with it in 1984 (Gonzaga 299).
} 
músicos emergentes no boom da música portuguesa, artistas, gente ligada à moda," among whom Variações stands out as a rare bird, "uma figura estranha, uma ave rara, com aquela estridentíssima voz minhota" (193). Gonzaga's account offers a menagerie of exotic specimens, from transvestites to artists and fashionistas. Yet, she differentiates Variações by his strident voice, declaring it a telltale mark of his birthplace. The description and designation refer to the shrill singing that characterizes the folkloric traditions of Minho in Northern Portugal, with a vocal style that André Araújo argues is most recognizable in female singers, whose voices he describes as "high-pitched, loud, intense" (29-37). Gonzaga marks Variações through a reference to tone and geography that also suggests a gendered ascription of his voice with the feminine characteristics of those folkloric singers from his childhood home. Among other flamboyant and rare birds, it is his voice, recognizable in style as Portuguese and suggestive of folkloricfeminine tradition, that is queerly situated in Lisbon's progressive postrevolution nightlife.

His debut recording, however, suggests a different geography, locating Variações not in the folkloric North but within Lisbon's fado. In accounts by contemporaries, Variações was deliberately enigmatic about ascribing an origin point for his music, suggesting somewhere between the Northern Portuguese city of Braga and New York (Gonzaga 208). It is both an anchoring in and an unmooring from Portuguese folkloric traditions and the progressive rock and new wave of Anglo-American music scenes as sites of inspiration. ${ }^{2}$ Though Variações suggests an unknowability of place, his first release points to fado as a site of vocal and stylistic affinity. While his two-track debut features "Estou Além," replete with the synthesizers and rhythms of contemporary new wave rock influences, Variações's remake of "Povo que lavas no rio," originally recorded by Amália Rodrigues and lionizing the harsh life of common folk in rural Portugal, serves as a provocative counterpoint. The fado is remade on this release with a disregard for conventional instrumentation and arrangement, while the choice of song and Variações's vocal styling invoke the repertoires and techniques of the genre's female performers. Moreover, through a transgressive embodiment of the female fadista in its differing affective forms, he makes a queer claim on Portuguese cultural practices sedimented as national heritage.

\footnotetext{
${ }^{2}$ On these sources, especially Joy Division and other post-punk and new wave bands, see Cardoso.
} 


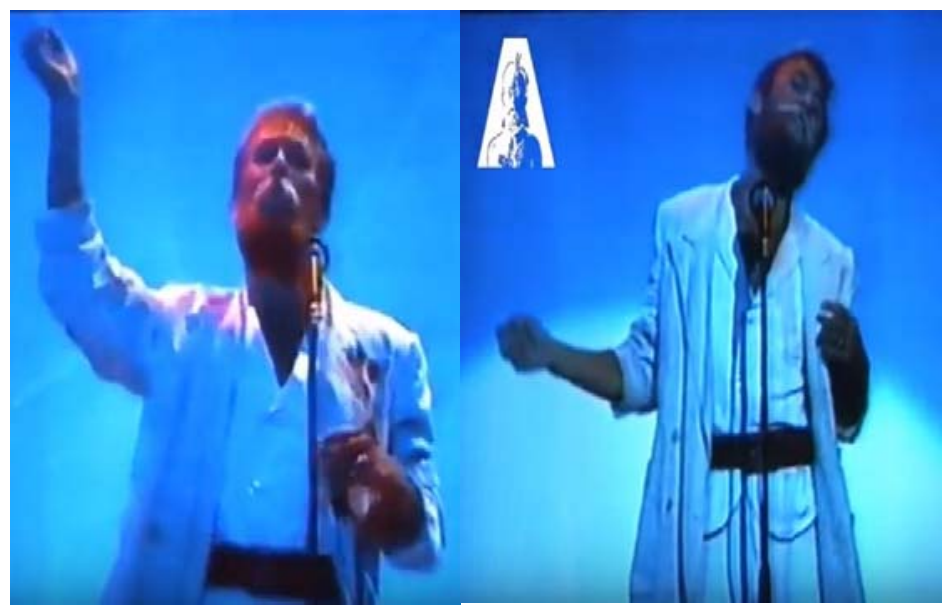

Fig. 1. António Variações, RTP 1982.

Appearing on RTP's Retrato de família in 1982 to perform the recently released "Povo que lavas no rio,"Variações takes the stage dressed in white with a long blazer and white shirt unbuttoned to show a peek of his chest, pants hugging the curves of his legs, and a black sash around his waist (fig.1). The arrangement renders the fado a brooding post-punk rock song with electric guitars, buzzing synthesizer, and droning drums. Variações, in mustache and thick beard, sensuously whips his arms up around his head and back down again in a kind of dance, drawing attention to his body, his hair, and his face, emphasizing the drama of the song. While the instrumentation deviates considerably from the original, he sings with sliding glissandos and shimmering melismas - vocal ornamentations that are the hallmarks of fado performance.

Variações's recording of fado and proclivity for its vocal techniques, when considered alongside his homoerotic performances and compositions, provoke a consideration of the genre's affective dispersions of sex. Vocal ornamentations in fado are commonly referred to as voltinhas or "little turns," a word that can also mean a stroll or jaunt, and may informally suggest a sexual tryst, marking voltinhas in fado as suggestive movements that deviate from the melody in heightened moments of drama. These "improvisatory vocal turns," as Lila Ellen Gray defines them, were popularized by Amália in the 1950s and 60s (81). Many performers describe them as the heart of fado, allowing listeners "to feel more" in moments "where it seems everything is going to explode" (40). António 
Pinheiro, the producer of Variações's second album, Dar e receber (1984), found Variações's use of these ornamentations strange at first: "Estranhei todas as modulações e a maneira como ele metia as modulações, ele faz muitos melismas na voz" (Gonzaga 244). Pinheiro's confusion underscores how such voltinhas were out of place in Lisbon's underground music scene, yet they are deployed by Variações in a vocal landscape of fado topography, marked by dramatic turns of improvisation that sound out particulary feminine desire and deviance.

Variações's voltinhas take up the gendered labor of the feminine voice in fado. Gray shows how men and women play different roles in fado practice, and how the woman's voice takes on particular affective structures (158-59). The differing iterations of the feminine in fado may be "weepy or tearful," and represented "as sacrificial, the eternal mother, as Mary, as the victim of male betrayal, as beaten down, as a prostitute or femme fatale with cigarette in hand, as melodramatic-Madonna, whore, mother" (Gray 162). Though fado repertoires cover a wide spectrum of emotions and scenarios, the feminine form can shape-shift from "illicit siren" to "mother-nation" (Gray 164). Fado's improvisatory tactics also allow women performers to "seize fado's conventions of spectacularized high melodrama" more readily (Gray 177-78). Variações's use of voltinhas upsets this coded affective repertoire. Gray argues that fado is "a catchment of affect and of story... that binds people to place and to one another" (5), marking a relationality between participants and sites, between admirers and performers, and between bodies and narratives. It is a process of embodied encounter that affectively entangles performer and public in illicit and unexpected ways. These encounters take a queer turn through Variações, consistent with Eve Sedgwick's notion of queerness as "relational and strange" (Tendencies viii). They are relational through references to Portuguese popular culture contingent on and constitutive of collective social practices; and they are made strange through Variações's disruption of gender and genre conventions. Put another way, Variações refigures the fadista and her vocal repertoire through his body and voice in a trans formation that casts fado as affect and story of queer bodies and desires, making its public complicit in the process.

Thinking fado as queer affect and story through Variações foregrounds the genre in deviance. Fado performances emerge as a transgressive and promiscuous relationality of bodies marked by moments of intensity. Improvisatory vocal turns drag out suspense, agony, ache, and take the listener 
up in body and breath, turning them on, or turning them off - as was the case for music critic Trindade Santos. In a TV TOP review from 1982, Santos declares Variações's refigured fado a serious contender for top prize in bad taste that year. He first praises the instrumentation - "Apoia-se numa fórmula bem concebida, que consiste na utilização de um discreto suporte harmónico e rítmico (sintetizado) sobre o qual a voz debita a sua parte" (52) - but disparages the vocals: "A instrumentalização suporta-se. A voz é que não" (52). More than a criticism of talent, this pithy complaint casts as indiscretion the artist's embodiment of fadista by marking the musical arrangement, in all of its postpunk and new wave irreverence, as a discreet support for an "unbearable" vocal styling. What is most intolerable here is how Variações's singing upends fado's gendered affectations and polemicizes its sexuality. It is also a productive point of departure to consider Variações as an unbearable fadista in a genealogy of fado divas that have been mythologized and idolized in unbearable relationships with their public. Rather than a genre rendered deviant through Variações's take on a classic, this genealogy reveals a history of fado's affective dispersion of sex as praxis for nonnormative desires.

Lauren Berlant and Lee Edelman have argued that sex is "the unbearable," a set of relations that both "overwhelm and anchor us," where "enjoyment itself can be unbearable," and where we "negotiate intimate estrangement" by "both holding fast to and moving beyond our accustomed ways of experiencing ourselves and our connectedness to others" (vii). They go on to claim that sex is a "site at which relationality is invested with hopes, expectations, and anxieties that are often experienced as unbearable" (vii). This does not ignore the fact that sex is "subject to the pressures of legal sanction, social judgment, unconscious drives, and contradictory desires" (vii); however, it nonetheless "holds out the prospect of discovering new ways of being and of being in the world," all while raising the possibility of "confronting our limit in ourselves or in another, of being inundated psychically or emotionally" (vii). Framing fado as an unbearable experience brings to the fore the formative intimacy of its practice and affective inundations as a scene of sexuality. Furthermore, it underscores fado performance as that which both overwhelms and anchors its participants, a social practice intimately felt that is also a cornerstone of Portuguese cultural heritage and national identity. Variações as fadista exposes a history of unbearable 
intimacy and embodiment that has permeated fado mythology since the making of the genre's first diva.

\section{Desiring the Unbearable-Maria Severa}

Severa looms as a kind of avatar in fado mythology, notable for her Romani origins, her work as a prostitute, and her notoriety as a singer from Lisbon's urban underbelly. While Severa is linked to nineteenth century Lisbon, Kimberly Holton brings together a historiography of fado that locates the genre's genesis in the colonial transit of the Lusophone Atlantic, noting the itinerancy of cultural actors and influences as a distinct characteristic of fado's origins, which "developed in both Portugal and Brazil precisely because of the similarly diverse array of portuary denizens" ("Fado Historiography" 7). Rui Vieira Nery likewise argues that emerging fado forms along these routes served as vehicles of communication, with "elites in Brazil trying all the time to imitate what they considered to be the latest fashion in the capital, but with Lisbon in its turn allowing itself to be seduced by Brazilian songs and dances" (52). Nery sexualizes this exchange as seductive interplay. Yet, colonial power dynamics produced asymmetrical exchanges and fado was relegated to peripheral people and places: ports, docks, brothels, taverns, and ethnic enclaves. Though fadista has come to mean a performer of fado, António Osório notes that it was primarily "um tipo sociológico" during the nineteenth century (32). Early fado historian, Pinto de Carvalho, likewise characterized the fadista as a "producto heteromorfo de todo o vício" (31).

By the turn of the twentieth century, Severa had emerged as an icon of the genre that embodied its seductive, illicit and ill-fated characteristics. Michael Colvin notes the importance of Júlio Dantas's novel A Severa (1901) and the first Portuguese sound film, A Severa (1931) by Leitão de Barros, based on Dantas's earlier work, as pivotal in cementing Severa's characterization and legacy (The Reconstruction 31). Where facts of Severa's biography are scant, legend fills in the gaps. Born as Maria Severa Onofriana in Lisbon in 1820, the daughter of a Romani prostitute who also owned a tavern, Severa took up the sex trade, became renowned for her singing, had an affair with the Count of Vimioso, and died of tuberculosis in 1846 at the age of twenty-six (Colvin, The Reconstruction 31). Her story has become a mainstay of fado narrative and discourse. Gray argues 
that the Severa legend usually "maps onto contestations regarding fado origins," emphasizing that "Severa was from the lower class, rising through [illicit] association with royalty (just as fado as a genre 'ascended' from the lower classes to the higher)" (163). Notably, however, the fictionalized Severa materializes as more than just aspirational myth of class mobility. Dantas's work dramatizes Severa as overtly and explicitly sexual, marking not only her social transgressions but also her body as key vectors of her fadista abilities.

Dantas drama has Severa seducing the Count of Marialva, a fictional standin for the Count of Vimioso, in a scandalous affair. Jealous of her other admirers, he accuses her of infidelity and locks her up in his apartment. She escapes by jumping from a window. When the Count threatens the simpleton Custódia, her most loyal suitor, Severa publicly berates Marialva and he abandons her only to return too late. A heartbroken Severa dies while strumming a guitar and singing a fado. Tiago Baptista argues: “A fadista não morre apenas pelo conde, mas também pelo fado. [...] Desistir da vida, para a Severa, significa abdicar de um amor impossível e conformar-se ao seu estatuto de subalternidade social em relação ao conde" (92). Baptista underscores Severa's death as a surrender to fate in her failure to rise above her social class. A fate of heartbreak, abandonment and death by fado are the markers of the Severa myth. Through her escape from the Count's home, Severa had rejected a capitulation to proper society. Even as she desired him, she refused his way of life, while romancing and fantasizing with her other suitors. She ran from the normative trappings of life with the Count, choosing instead the world of the fado.

Yet, Dantas collapses Severa's talent for singing fado onto her body as sexual and desirous being. While Severa may have failed to cross a class divide from deviant mistress to respectable wife, Dantas presents her with a virility that traverses gendered class distinctions and non-normative sexuality, offering a reading of Severa and her death as site of queer potentiality. The character Diogo describes her as "a maior fadista cá da Mouraria. Quando canta, parece que a alma da gente vai atrás dela. Mas, sangue de cigana, braço peludo e lume no olho. Não é quem quer, é quem ela quer" (17). Severa, he claims, is the greatest fadista of Lisbon's old Muslim quarter, a neighborhood branded by prostitution and violent crime in the nineteenth century that was ultimately dismantled in the twentieth century (Colvin, The Reconstruction 21). Beyond localizing Severa in a seedy, ill-fated neighborhood, the description exoticizes her Romani heritage, 
Silva

imbues her with a deviant sexuality, and describes her body as bordering on the monstrous. Diogo warns of her Romani blood, her hairy arms, and the fire in her eyes before proclaiming that Severa will have whom she wants, an allusion to her ability to choose her own sexual partners that feels more like an inticing but dangerous threat. While her voice is said to captivate the souls of her listeners, it is her sexuality and her body that punctuate Severa simultaneously as desirable and aberrant.

Severa's sexuality, in its virility and volatility, comes into sharper focus in contrast to the Count of Marialva, who represents a romantic Portuguese stereotype of a womanizing nobleman that emerged in the late eighteenth-century as a caricature of the "bullfighter, equestrian, and whoremonger," named after the Marquis of Marialva (Colvin, Fado and the Urban Poor 62). Miguel Vale de Almeida regards marialvismo as "a moral and ideological discourse on hierarchy, gender and national identity shaping specific social practices" (5). Dantas's Marialva is paradigmatic of what Colvin calls a "maverick figure, defying the mores of society" by frequenting exotic, lower-class fadista milieus (Fado and the Urban Poor 63). He is matched, however, in fight and sexual prowess, by Severa in a seeming conflict of gender roles. Throughout the drama, she loves and leaves him, confronts him in public, hits and lashes out at him, and maintains her other suitors without giving up control. When imprisoned by the Count's jealousy, she rejects him and escapes back to life on her own turf and terms.

Severa possesses what Lauren Berlant refers to as "libidinal unruliness," something which "heteronormativity attempts to snuff out" (4). Pointing to Gayle Rubin's demarcation of "sexual outlaws," Berlant marks these outlaws as populations cast as "moral and political threats that must be framed, shamed, monitored, and vanquished if the conventional good life [...] is going to endure" (5). The Count seeks to tame Severa's unruliness and vanquish her libido through seclusion and monogamy. Patricia Vieira, writing on Leitão de Barros's film A Severa (1931), argues similarly that Severa "proves to be an independent, protofeminist woman who endangers established morality. [...] It is patently impossible to chain Severa's libertarian drive and force her to accept an innocuous social position as the domesticated and silent lover of an influential man. The only solution is the death of the protagonist" (158).

Notably, however, Rubin underscores how some queer communities "have developed elaborate technology for building public institutions for sexual 
outlaws" (131). Rubin allows a useful turn from the vanquishing of Severa as sexual outlaw toward fado practice as a public institution in which sexual outlaws have thrived, and where Severa's libidinal unruliness has been forever enshrined in fado lore. The fadista as sexual outlaw suggests that participation in the genre is a promiscuous affair, charged with illicit drives and desires. As evidence, Dantas's drama ends with Severa's death unfolding as a fado performance. She sings and dies while the Count of Marialva and Severa's ever-loyal admirer Custódia embrace one other, enmity forgotten, intimately connected and overwhelmed by Severa. Rather than assimilation into or destruction by normative conventions of gender and sexuality, Severa as nexus of fado and desire, even in death, engenders a promiscuous and homosocial scene inundated with queer intimacy.

\section{Unbearable Nationalism-Amália Rodrigues}

In fado's transition from a practice of Lisbon's peripheries to codified expressive practice of Portuguese culture, Severa's transgressive sexuality was dispersed as a sublime relationship with the nation that was concomitant with the rise of Amália Rodrigues as the genre's most famous star. Through Amália, the paradigmatic fadista underwent a significant transition from seedy siren to mother-nation. Under António Salazar's authoritarian Estado Novo regime, the fadista took the form of a woman more consistent with official ideology. By the mid-twentieth century, fado had been displaced from Lisbon's nightlife and projected as national heritage, gaining international recognition through Amália, while Estado Novo's censorship diluted and diffused fado themes and references. Though Amália was cast in several films about fado that took up and revised the Severa mythology of doomed class-crossed romance, Tiago Baptista argues, “[Amália] parece ter afastado da representação tradicional da fadista da Mouraria. [...] Não seria Amália a adaptar-se a Severa, mas sim a Severa a ajustar-se a Amália" (100). The fadista severiana, deviant and doomed, gave way to the fadista amaliana as the voice of a collective Portuguese condition. The illicit fadista was made penitent, tasked with representing the nation as it was rendered under the catholic, conservative and corporatist policies of the Estado Novo. 
Fado was at first inconvenient to Estado Novo ideology for its association with urban vice, its use as social protest, ${ }^{3}$ and its forlorn postures. From its onset in the 1930s, the regime promoted folkloric practices and impoverished rural life as spiritual counterbalance to the industrialized urban centers. ${ }^{4}$ Anxiety over gender roles are evidenced in state-produced pedagogical publications, one of which featured the ideal Portuguese family oriented around god, nation and patriarch, while the mother, wearing peasant garments, stands fully within the home's hearth, confined to the domestic space dangerously close to the fire ("A lição de Salazar"). Women were consigned to the home, and "economic independence and the emancipation [...] from masculine tutelage [was] discouraged" with fears that "women working outside of the home would trigger the dissolution of the family" (Vieira 161). Fado's popularity, however, provoked the regime to install an elaborate system of categorization, licensing and permitting of compositions, performers and venues. This institutional apparatus provoked self-censorship through revision, editing, and the use of allegory in an effort to attain permits and avoid trouble (Corte-Real 33).

Born in Lisbon in 1920 to parents who had traveled from the rural interior to the capital, Amália Rodrigues began to sing publicly in 1935 and debuted at fado houses in 1939 (Nery 327). Though she attained the highest level of celebrity for a Portuguese performer in her time, Gray argues that her rural and humble origins allowed Amália a legitimacy as "do povo," one of the people (187). Fado lore stresses Amália's "rag-to-riches life narrative, her humble upbringing, her working-class jobs, her lack of formal education and of formal voice training," while foregrounding "a voice and public figure who brought Portugal and fado to international attention" (Gray 185-87). While Amália was an independent artist, the regime also put her to work. She was sent abroad as a "Portuguese representative" (Gray 188), and the specter of the Estado Novo hovers over some of Amália's most iconic recordings, such as "Casa portuguesa" (1956), celebrating the humble poverty of a Portuguese home, and "Lisboa, não sejas francesa" (1955), admonishing Lisbon to be wary of foreign influences. Amália

\footnotetext{
${ }^{3}$ Colvin shows how fados could voice resistance through complaint. Nery shows how turn of the century fado reflected the ways in which "the daily lives of this community could not be other than marked by [its] precarious living conditions" (Fado and the Urban Poor 174). Fado took route in other places and other experiences, through students and university life in Coimbra, for example.

${ }^{4}$ Holton details the different competitions and incentives the regime organized to promote folklore as part of their fascist pedagogy.
} 
seems a contradiction of the Estado Novo's perfect peasant housewife - a professional performer, well-traveled, divorced and remarried with no children of her own; however, Nery notes that she was an "exception," a way for the regime to gain "various forms of political capital" (330).

While Severa's affective power is located in her body and through her sexuality, Amália's seems to be beyond her, located not in her body but in an essential Portuguese condition and in authentic Portuguese roots, emerging from the land and the people to which she gives a voice. Vítor Pavão dos Santos records Amália's attribution of her talent and technique to the folkloric songs of her mother's rural countryside:

A influência que tinha era da Beira Baixa. Daquelas ondas que o povo da Beira Baixa põe na voz quando canta. Não sei se será do trigo, porque lá não há mar, mas deve ser do trigo e do milho grosso. [...] Além disso, trazia dentro de mim o sangue e a raça daquela gente. [...] Mas como nasci em Lisboa transportei essa forma de cantar para o fado. (O Fado 42)

In contrast to Severa's gypsy blood, hairy arms and fiery eyes, Amália locates her fado in rippling waves of wheat and corn flowing through the blood of peasant folk. The remark resonates as the full dislocation of fado away from Lisbon, its ports, and its circum-Atlantic origins, rooted through Amália in an inland, rural and authentically Portuguese geography. She is in this way a disembodied voice. Her fado is not her own but that of the nation, abstracted as a resonating voice. Her body also transforms the paradigmatic fadista in performance at a time when women's bodies were jealously claimed and guarded by the governing regime's restrictive social mores and policies. Amália popularizes the use of a black shawl as modest cover up and marker of mourning and piety. She performs standing behind her guitarists, rather than in front, and often clasps her hands as if in prayer when she sings (Nery 332), eyes closed with her head titled back not in ecstasy but in supplication. 


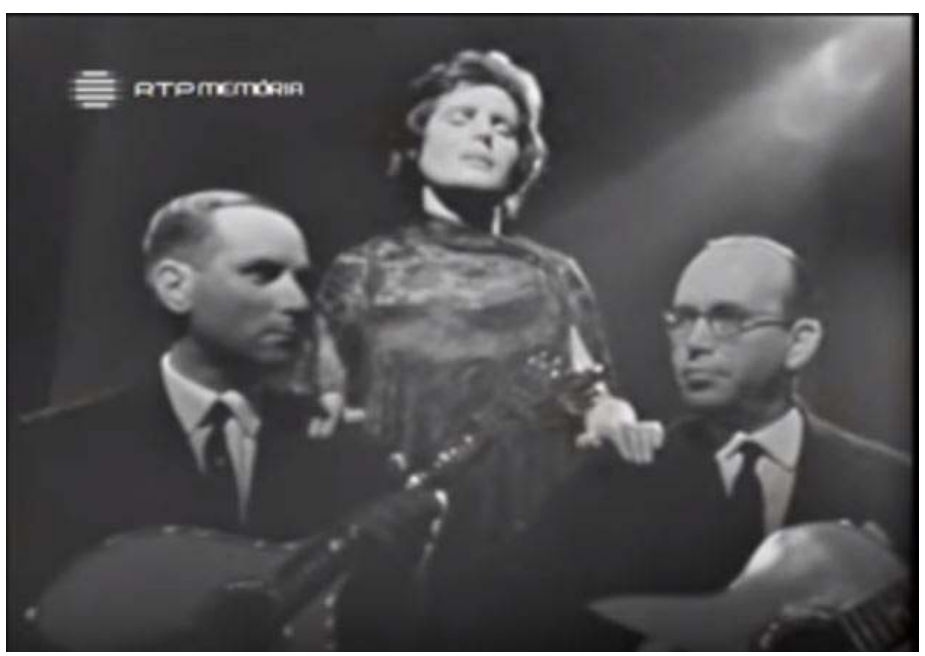

Fig. 2. Amália Rodrigues, "Povo que lavas no rio,” RTP, 1961.

Amália as the ultimate expression of an essential, and shared Portuguese condition cements her as the definitive fadista, a new classic, voicing the eternal Portuguese saudade, which Gray argues "came to broadly signify the sense of feeling, history, uniqueness, and time of the Portuguese people and nation [...] the "essence' of the 'Portuguese soul'" (Gray 83). Amália's conflation with fado, and fado with Estado Novo myth-making, lingered after the fall of the regime in 1974, and in post-revolution reckoning with decades past, some saw fado and by extension Amália as complicit in the regime's crimes and stagnation (Nery 338). Amália as cultural agent of Estado Novo ideology, however, is complicated by the ways in which she circumvented institutional stranglehold and came into tension with the regime as one of its reluctant, if not entirely unwilling, actors. Nery argues, "[Amália] followed an artistic path entirely [of] her own criteria, which was characterized by constant rebellion before the established traditions of the genre" (332). She was criticized for expanding fado into literary and artistic domains, putting some of Portugal's most notable poets to music, having poetry written specifically for her and writing her own poetry for fados, usually the domain of men within the gendered labor of fado practice. Her collaborations with Alain Oulman, first appearing on her 1962 album Busto/Asas fechadas, which featured the original recording of "Povo que lavas no rio," are notable for their deviations from fado's standard forms. Also on Busto, "Abandono" criticized the imprisonment of political dissenters. Though Amália claimed to not 
have associated the song with such criticism (V. Santos, Amália 139), Oulman was imprisoned and expelled from Portugal (Nery 344). By the time of her death in 1999, Amália's reputation had recovered, and she was buried alongside monarchs, though not without controversy. ${ }^{5}$

Paradoxically, though Severa was primarily myth, her body looms within her narrative as a sexual, unruly and desiring woman, while Amália's life and career, documented and televised, were in many ways abstracted as "a collection and interplay of multiple phenomena" (Gray 194). The sculpted bust of Amália on the album cover for Busto eerily suggests the diva disembodied and cemented as statuary, an immortalization of the fadista that renders her lifeless, a fado reliquary. Busto, however, is also the album through which Amália breathes new life into the genre through unexpected collaborations with Oulman and also with Luis de Macedo and David Mourão-Ferreira. Susana Sardo argues that Amália in the 1960s "é talvez a fadista que melhores condições reúne para produzir [...] uma viragem no modo de conceber este género" (Sardo 455), suggesting Amália as an authority of the genre, able to intervene and transform its repertoire, and, by extension, repertoires of Portuguese heritage. Though disembodied, her voice could move, touch, change, and make meaning of Portuguese life as it was lived and practiced.

Through her pivotal role for fado and, through the genre, for the understanding and unfolding of the Portuguese character, Amália's voice is often described as provoking an ecstatic relationship between fan, fadista and national identity. Gray argues that Amália's voice "so went beyond itself that for many it became a means of deeply shaping personal subjectivity [...] a way of feeling Portuguese" (185). Moreover, "Fans, fadistas, and instrumentalists emphasize the affective power of Amália's voice as what enabled her to sing to the intimate, to the local, while singing to the world" (Gray 197). Notably, while Amália may have transformed the fadista from deviant to demure, a live performance on Portuguese national television in 1961 of "Povo que lavas no rio" shows how she rests her hands on her guitarists' shoulders, a tactile manifestation of her authoritative presence, her implicit capacity to touch people, and a potential

\footnotetext{
${ }^{5}$ When Amália died in 1999, the Portuguese government declared three days of national mourning. She was first buried in a parish cemetery, while debates transpired over whether a female fadista deserved such an honor or if even the Pantheon was not enough for someone of her importance (Gray 180).
} 
betrayal of the underlying and marked sexuality of the fadista. Amália's touch is a suggestive move that disarms and makes vulnerable guitarist and audience in anticipation (fig. 2). Moreover, Ardent fans self-identify as amalianos and describe their experience with Amália's voice, either in a memory of a live performance or experienced through recorded media, as "a divine, transcendent experience," while one amaliano declares it "a voice which completely makes one feel dizzy and drunk" (Gray 200-3). Through a vocabulary that suggests passion and penetration, they show how Amália's voice overwhelms, taking the listener up in a thrilling and unbearable experience.

The interplay of affective intimacy between the fadista and her public is the subject of "Povo que lavas no rio," magnified in its verses. The song romanticizes a life of toil, reminiscent of Estado Novo fascination with poverty as pageantry. Yet, beyond glorifying a rural way of life, the fado's verses lay bare a relationship between performer and povo that turns the emphasis away from the public's experience and toward the fadista's desire, with each stanza addressing the people outright, unfolding a charged and sensual exchange. By taking up this fado, Variações exploits the penetrative power of the fadista with queer intent, inserting his body as protagonist in a story of desire and of fado as a constitutive social practice that enmeshes queer and normative Portuguese subjectivities alike. Beyond homage to Amália, of whom he was an ardent fan, Variações harnesses the cultural and social terrain through which he emerged and thrived, claiming this heritage and practice as his own, and revealing a history of fado as queer praxis in the process.

\section{Fado Trans Formations -António Variações}

Variações as fadista inhabits Severa's deviant sexuality as queer masculinity and refigures Amália's voice by taking up her fado through his own melismas and voltinhas, making fado and Portuguese heritage complicit in his nonnormative desires. Though he did not publicly discuss his homosexuality, Variações put it on extravagant display. He was well-known in Lisbon not only as a unisex barber, but also for his transgressive performances and style. ${ }^{6}$ His albums, videos and

\footnotetext{
${ }^{6}$ Gonzaga details Variações's early notoriety and offers a series of photos that document his transgressive styling and creative output.
} 
performances celebrate a queer life locally situated in Portuguese social and cultural contexts. A TV broadcast of Variações performing "O corpo é que paga" (1983) shows him, at 2:15 into the video, bare-chested in a leather harness and straps, loosely whipping himself as he danced (PortugalMetal). Bondage and sadomasochism are alluded to in the song's verses about the body in pleasurable pain. On the cover art for Povo que lavas no rio/Estou além he is wrapped in scarves and fabrics in hues of pink and purple with deep cleavage revealing his hairy chest (fig. 3). The image recalls the dramatization of Severa as exotic, hairy and with a virility that transgressed gender roles. Variações takes up the trans implication of Severa as sexual outlaw and materializes the deviance outright as a gay man notorious in Lisbon's demi-monde turned national popstar singing in the gendered codes of fado.

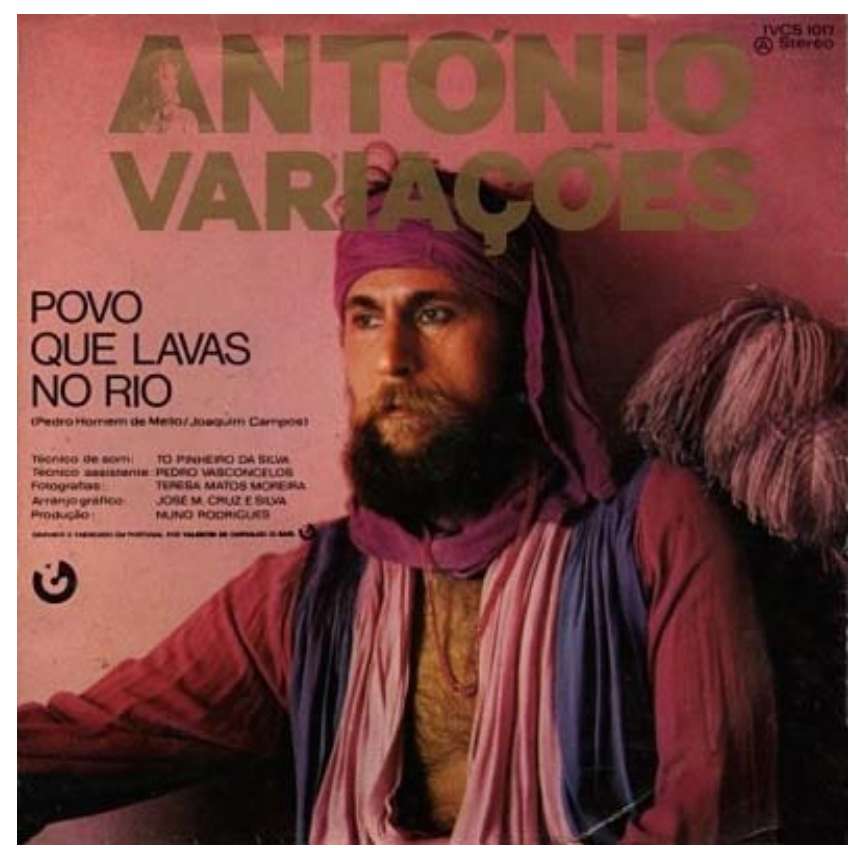

Fig. 3. António Variações, Povo que lavas no rio/Estou além, Valentim de Carvalho/EMI, 1982.

Richard Elliott notes Variações's intervention in "both fado and Portuguese pop" as "an openly homosexual appropriation of Portuguese music tradition" (145). Yet, homosexuality had circled around fado from its outset. António Botto, 
whom Anna Klobucka considers possibly the first publicly queer Portuguese personality for writing openly "homoerotic verse, prose and drama" (Klobucka 110), was given a fado performance by Amália Rodrigues as a fundraiser for his eventual exile to Brazil in the 1940s (S.J. Almeida 98). He also wrote about a stroll that never happened through the fado houses of Lisbon's Bairro Alto "listening to fado performances" with Federico García Lorca, whom he had never met (Klobucka 117). Botto was not an anomaly in his homosexual voltinhas in public or in private. During the Estado Novo, despite constraints and risk, male same-sex acts played out in relatively public places. ${ }^{7}$ São José Almeida's history of homosexuality under the Estado Novo lists many rumored homosexuals in Portugal during that time, noting how Salazar showed complacency for gay men in elite circles while stifling public discussion, rendering homosexual acts an "unmentionable" but widely practiced vice (127-130). A contemporary of Pedro Homem de Melo, author of the poem that would become "Povo que lavas no rio," describes him as "assumido, toda a gente no Porto sabia, mas não se falava" (S.J. Almeida 176), suggesting Melo's homosexuality as a well-known fact. Another of his poems, "O rapaz da camisola verde" (1954), recorded as a fado by Amália, depicts a scene of gay patronage where an elite john cruises his lower-class object of desire. ${ }^{8}$

Fado has been a part of queer lives both real and imagined throughout its practice. Variações's recording of "Povo que lavas no rio," prods at Melo's homosexuality and points to the genre's glass closets. Eve Sedgwick describes the "open secret" and "glass closet" of homosexuality as "shaped by the conjunction of an extravagance of deniability and an extravagance of flamboyant display" (Epistemology 165). Throughout the twentieth century, while the Estado Novo mediated homosexuality through a culture of silence and political favor, their misogynist ideologies privileged Portuguese masculinity and their aggressive folklorization romanticized men's labor. Melo's "Povo" similarly exploits the cultural fascination with rurality by fetishizing the folk, articulating their bodies and labors in a grammar of affect and desire. João Vasconcelos

\footnotetext{
${ }^{7}$ Homosexuality had been criminalized since 1912, and "the Penal Code of 1966 stipulated a maximum two-year sentence for repeated "indecent assault on someone of the same sex" (A.C. Santos 43). See also Bastos. São José Almeida recounts a street culture of furtive sexual encounters in public urinals and gardens (170).

${ }^{8}$ São José Almeida points out how Variações would later set a similar gay cruising scene in his song "Canção do engate" (182).
} 
argues, "O povo dos poemas de Homem de Melo é um ser essencialmente corporal, são músculos e sangue, é sensualidade pura" (466). If Amália was the voice of the nation, Melo's poem suggests its body as a corporeal mass of rustic men. Though the song's title calls out to the people who wash in the river, describing laundry practices that would have been woman's work, the verses move toward masculine domains with references to the land, to agriculture, to socializing and drinking.

Fui ter à mesa redonda,

Beber em malga que esconda

O beijo de mão em mão.

Era o vinho que me deste

Água pura, fruto agreste

Mas a tua vida não.

Aromas, de urze e de lama,

Dormi com eles na cama

Tive a mesma condição.

Povo, povo, eu te pertenço,

Deste-me alturas de incenso,

Mas a tua vida não.

Melo wrote himself in an intimate relationship with the povo while insisting on an inevitable distance between them. Richard Elliott writes, "The poet Homem de Melo and the singer Rodrigues take on the responsibility of hymning the people while also observing them at a geographical and temporal distance" (54). Though Elliott tasks them both with authorial labor, the poet is ultimately surpassed by Amália's voice through which these verses became affective heritage as a fado. Amália's voice obscures the poet's hand and hides the homoerotic implication of Melo's work underscored by his rumored homosexuality. Serving as a glass closet, Amália's voice occludes Melo's fetish as the voice of mother-nation addressing muddied and weathered men in a heteronormative and nationalist fantasy.

Variações reinscribes Melo's words with homosexual desire and reclaims this fado as a queer narrative. While the lyrics speak to a remoteness between 
Silva

fadista and folk, they betray a physical intimacy that upends that distance and, sung by Variações, take on an overtly sexual nature. Variações shares wine with these men, in a communal bowl passed hand to hand as if sharing a kiss; he sleeps with them, overwhelmed by the mass of muscle with scents of heather and mud. He is a part of them only ever through the affective experience of their bodies. In his televised performance of this fado, his sensual swaying eroticizes this bodily experience, while his voltinhas both invoke Amália's imprint and supplant her disembodied voice with his embodied stage presence. Through him, the ending of each stanza seems less to suggest resignation at the inevitable distance between the marked fadista and the simple folk, and more a defiant rejection of their normative way of life, even as he desires and loves them. The queer potential of Severa's death by fado is realized in Variações's "Mas a tua vida não."

In arrangement, performance and vocal technique, Variações's exploits the potential for transgression that resides in the genre as both improvisatory tactics and deviant sexuality. Improvisation in both performance and gender functions as a tool of citation and aberration, theorized as "an act of collective memory and invention" (Parker 61), as the simultaneous "constraints and production of political possibilities as these emerge from the constant choreography of [...] meaningful movement and [...] subversion" (Delgado 18). Fado's deviance, its silences, its interruptions, the dragging out of moments in dramatic heights and cascading drops, lend themselves to a queer praxis that is not foreclosed on by fixed identity, but elaborated through practices of "circuitousness, evasion, [and] avoidance," akin to what José Quiroga argues are "not necessarily forms of denial [but] particular ways of saying" (80). Judith Butler's troubling of gender as "a practice of improvisation within a scene of constraint," also offers improvisation as the key to gender's undoing (1). Invested with a repertoire of suggestive deviations, charged silences and overwhelming experiences, Variações's provocative turn as fadista pulls at the constraints of gender and genre in their formative functions for Portuguese cultural heritage and political subjectivity.

Variações as a trans formation of fadista through willful deviation of breath, voice, and body makes explicit a relationality of sex and desire lurking under nationalist sentiment and codified cultural norms. His performance is neither a caricature nor drag rendition of fado. Rather, Variações disidentifies with fado's sedimented, heteronormative cultural tropes and conventions. Reviving the illicit desire of the genre's feminine form, crossing its gendered codes and adding 
masculine flesh to Amália's voice, he renews its affective structures through a tactical process that refigures toxic traps into what José Esteban Muñoz calls "antinormative treasure troves of queer possibility" (Muñoz x). Variações collapses the deviant, the folk and the nation in his formation of fadista. His styling, beard and chest recall Severa's body hair and the fetishized masculinity of Melo's rustic povo, while his voice and movements invoke the authentic stamp of Amália's voice while asserting a queer claim to its affective resonances.

By 1982, with a revised penal code, democratic Portugal saw significant changes to "moral standards, attitudes and behaviors," with new dialogues and visibility for women's rights, homosexuality and sexual intimacy, the decriminalization of sex acts between consenting adults in private, as well as drag queen "entertainers [who] gained nationwide visibility" (A.C. Santos 45). Notably, Variações's abrupt death in 1984 pushed his sexuality into the public sphere as newspapers suspiciously posited in print the possibility of Variações having died from AIDS (Gonzaga 299). They also just as quickly circumvented his homosexuality and cause of death to honor his music. ${ }^{9}$ A contemporary of Variações suggests that his implicit outing hurt sales of his second album Dar $e$ receber, released weeks prior to his passing. "A ideia que o António podia ter morrido de Sida fazia muita impressão às pessoas, naquela altura. E não ajudou nada à vida do segundo LP do António" (Gonzaga 308). While his music and performances had put queer sexuality on display, his death decontextualized his homosexuality from Portuguese references, displacing Variações from collective affective heritage and onto unmediated ground beyond too visceral and unbearable of a limit for society at large to cross.

Nevertheless, Elliott argues that Variações suggested "the way the 1980s might sound" in Portugal, by directing the progressive turns of modern music through the registers of Portuguese genres. Yet, he also materialized queer desire as a terrain upon which the affective repertoires of Portuguese heritage move and map. He emerges as site of queer thriving that is locally defined, entangled with the normative practices and sexualities of Portuguese culture, even as he fails to succumb to their conventions. Beyond how the 1980s might sound, Variações serves as an example of how queer Portuguese expressions might live and love,

\footnotetext{
${ }^{9}$ See, for example, "A nossa capa," in which the editors of TV Top explain, days after Variações's funeral, that the use of his image for the issue's cover is in remembrance of him and not to participate in any speculation regarding his cause of death.
} 
how nonnormative bodies and desires may also lay claim to fado not only as national mythology but as affective and constitutive social practice. The resonances of Variações's pioneering can be felt through other fadistas: in the "androgynous nature" of Gonçalo Salgueiro's performances (Elliott 171), and Paulo Bragança's irreverent and punk aesthetic (Elliott 146), and in Gisela João's 2016 video for "Labirinto," written by David Mourão-Ferreira, which features Fernando Santos in his drag persona Deborah Kristall lip-synching the fado to João's voice.

More recently, Lila Fadista offers a trans formation of fadista in her Fado Bicha performances, which have taken place at various venues in Lisbon and beyond, including Lisbon's Cinema São Jorge and FavelaLX, and Favela2.0 in Berlin. Favela2.0 promoted the Fado Bicha nights by underscoring fado's deviant roots and routes, suggesting Lila as the latest iteration in fado's unbearable genealogy:

O fado nasceu das bocas dos marginais e maculados, das prostitutas e enjeitadas, dos bêbedos, dos marialvas e marujos sem eira nem beira, rufiões e tatuados. Foi depois polido e adotado pelas elites portuguesas mas pertence à rua, à viela, à sarjeta. E à Favela. Lila é uma fadista com pelo na venta e no peito também. Casaco tigresse puído e copo de vinho barato na mão. Batam palmas e cantarolem com ela que o fado também é transgressão e alvoroço.

In her own words, Lila declares, "Acho que o fado é muito bicha e sempre foi, só faltava alguém pegar nele dessa maneira," expressing dismay at fado's heteronormative lyrical themes, which her guitarist and creative partner João Caçador argues have never represented outright the queer lives that have always participated in its practice (Monteiro).

While the poems and verses of the genre may ignore, encode and obscure nonnormative desire, its performance tactics and its history as social practice marked by deviant sexuality and unbearable affect say otherwise, threatening to upend its heteronormative themes. Performers more attuned to deviance and transgression will always fail fado's normative guise. Yet, Halberstam reminds us, "Failure allows us to escape the punishing norms that discipline behavior. [...] Failing is something queers do and have always done exceptionally well" when 
success "in a heteronormative, capitalist society equates too easily to specific forms of reproductive maturity" (The Queer Art 2-3). To punctuate this refiguring of failure as queer thriving, consider Gray's anecdote about a lesbian couple at a fado performance "with glazed looks of rapture on their face," who break with decorum when one reaches up and kisses the fadista's hand and hem of her skirt, inattentive to the snickering crowd (Gray 173-74). This moment underscores how fado as queer praxis fails the genre's conventions; how it invites rupture in a revealing kiss of the fadista's hand as a response to her overwhelming power; a kiss that reciprocates the intimacy and returns the touch.

\section{Works Cited}

Abreu, Rui Miguel. “A história secreta de António Variações.” Blitz, 10 Sept. 2017, blitz.sapo.pt/principal/update/2017-09-10-A-historia-secreta-deAntonio-Variacoes.

“A lição de Salazar." Visualizing Portugal, Massachusetts Institute of Technology, 2 Apr. 2013, visualizingportugal.com/ed-vn3-8-lessonssalazar/2013/4/2/a-lio-de-salazar.

Almeida, Miguel Vale de. "Marialvismo: A Portuguese Moral Discourse on Masculinity, Social Hierarchy, and Nationhood in the Transition to Modernity." Série Antropologia, vol. 184, 1995, repositorio.iscte.pt/ bitstream/10071/13827/1/Marialvismo.pdf.

Almeida, São José. Homossexuais no Estado Novo. Sextante, 2010.

"A nossa capa." TV Top, no. 173, 22 Jun. 1984, p. 2.

Antoniovariacoesofic, "António Variações|Povo que lavas no rio," YouTube, 23 May. 2010, www.youtube.com/watch?v=Sxjasfl2Y_w.

Araújo, André. "Características espectrais típicas do canto folclórico do Alto Minho.” Post-ip, vol. 2, no. 2, 2013, pp. 29-37.

Baptista, Tiago. Ver Amália. Tinta da China, 2009.

Bastos, Susana Pereira. O Estado Novo e os seus vadios: contribuição para o estudo das identidades marginais e da sua repressão. Dom Quixote, 1997.

Berlant, Lauren, and Lee Edelman. Sex, or the Unbearable. Duke UP, 2014.

Butler, Judith. Undoing Gender. Routledge, 2004.

Cardoso, Miguel Esteves. Escrítica pop. Assírio \& Alvim, 2003.

Carvalho, Pinto de. História do fado. Empreza da História de Portugal, 1903. 
Colvin, Michael. Fado and the Urban Poor in Portuguese Cinema of the 1930s and 1940s. Tamesis, 2016.

- The Reconstruction of Lisbon: Severa's Legacy and the Fado's Rewriting of Urban History. Bucknell UP, 2008.

Côrte-Real, Maria de São José. Cultural Policy and Musical Expression in Lisbon in the Transition from Dictatorship to Democracy (1960s-1980s). Columbia UP, 2001.

Dantas, Júlio. A severa. Brandão, 1900.

Delgado, Celeste Fraser, and José Esteban Muñoz. Everynight Life: Culture and Dance in Latin/o America. Duke UP, 1997.

Elliott, Richard. Fado and the Place of Longing. Ashgate, 2010.

Favela2.0. "Fado bicha." Facebook, 9 Mar. 2017, www.facebook.com/events/ 700837306763356/.

Gonzaga, Manuela. Entre Braga e Nova Iorque. Ancora, 2006.

Gray, Lila Ellen. Fado Resounding. Duke UP, 2012.

Halberstam, J Jack. In a Queer Time and Place. New York UP, 2005.

-. The Queer Art of Failure. Duke UP, 2011.

Holton, Kimberly DaCosta. "Fado Historiography: Old Myths and New Frontiers." P, vol. 0, no.1, 2006, pp. 1-17.

-. Performing Folklore: Ranchos Folclóricos from Lisbon to Newark. Indiana UP, 2005.

João, Gisela. "Laberinto ou não foi." YouTube, 10 Nov. 2016, www.youtube. $\mathrm{com} /$ watch?time_continue $=4 \& \mathrm{v}=\mathrm{jyA} 813 \mathrm{OUpOc}$.

Klobucka, Anna. “António Botto's Impossible Queerness of Being.” Portuguese Modernisms, edited by Steffen Dix and Jerónimo Pizzaro, Legenda, 2011, pp. 110-21.

Melo, Pedro Homem de. "Povo." Miserere. Portugália, 1948.

—. "O rapaz da camisola verde." O rapaz da camisola verde. Saber, 1954.

Monteiro, Paulo. "O fado é muito bicha e sempre foi, só faltava alguém pegar nele dessa maneira." Dezanove. 12 May. 2017, http://dezanove.pt/o-fado-emuito-bicha-e-sempre-foi-so-1134947.

Muñoz, José Esteban. Disidentifications: Queers of Color and the Performance of Politics. U of Minnesota P, 1999.

Nery, Rui Vieira. A History of Portuguese Fado. Casa da Moeda, 2012.

Osório, António. A mitologia fadista. Horizonte, 1974. 
Parker, Andrew, and Eve Kosofsky Sedgwick, editors. Performativity and Performance. Routledge, 1995.

PortugalMetal. "Imagens raras e exclusivas de António Variações (inclui entrevista)." YouTube, 7 Nov. 2008, www.youtube.com/watch? $\mathrm{v}=\mathrm{xhn}$ Wjukab50\&t=99s.

Quiroga, José. Tropics of Desire: Interventions from Queer Latino America. New York UP, 2000.

RTP, Retrato de família, 1982, www.youtube.com/watch?v=Sxjasfl2Y_w.

Rodrigues, Amália. Busto/Asas fechadas. Columbia, 1962.

—. "Lisboa não sejas francesa." Amália Rodrigues. Columbia, 1955.corpo é

—. "Uma casa portuguesa.” Amália Rodrigues 2: Fado et Flamenco. Columbia, 1956.

Rubin, Gayle. Deviations: A Gayle Rubin Reader. Duke UP, 2011.

Santos, Ana Cristina. Social Movements and Sexual Citizenship in Southern Europe. Palgrave Macmillan, 2013.

Santos, Trindade. “Crítica de discos.” TV Top, no. 65, 1982, p. 52.

Santos, Vítor Pavão dos. Amália: uma biografia. Presença, 2005.

—. O fado da tua voz: Amália e os poetas. Betrand, 2014.

Sardo, Susana. "Música popular e diferenças regionais." Multiculturalidade: raízes e estruturas. U Católica Portuguesa, 2009.

Sedgwick, Eve Kosofsky. Epistemology of the Closet. U of California P, 1990.

—. Tendencies. Duke UP, 1993.

Variações, António. Dar e receber. Valentim de Carvalho/EMI, 1984.

-. Povo que lavas no rio/Estou além. Valentim de Carvalho/EMI,1982.

Vasconcelos, João. "O povo enquanto libido no folclorismo poético de Pedro Homem de Melo (1904-1984)." Vozes do povo, edited by Salwa El-Shawan Castelo-Branco and Jorge Freitas Branco, Celta, 2003.

Vieira, Patricia. Portuguese Film, 1930-1960. Bloomsbury Academic, 2013. 